\title{
JĘZYKOWE SPOSOBY WYRAŻANIA EKSPRESJI. TOMASZ RACZEK O DZIENNIKARZACH
}

Tomasz Raczek jest znanym w Polsce krytykiem filmowym, publicysta, twórca programów radiowych i telewizyjnych. W swoich felietonach przez pryzmat filmu, kina, telewizji odnosi się do teraźniejszego życia społecznego. Swoja postawę wobec rzeczywistości wyraża przez odwołania do świata medialnego. Charakteryzuje go stylistyczna swoboda w poruszaniu się po tematyce medialnej, w dygresyjny sposób mówi o obecnych postawach wobec zastanej rzeczywistości, polemizuje $z$ innymi tekstami, a przy tym nie parodiuje zachowań ludzi. ${ }^{1}$ Swoje felietony publikował m.in. we „Wprost” pod wspólnym tytułem Ekran osobisty (od stycznia 1991 roku do sierpnia 2005 roku).

Zgodnie $z$ definicją Michała Głowińskiego, zawartą we współczesnym słowniku terminów literackich, felieton to:

jeden $z$ podstawowych gatunków prasowych: odznacza się swobodą stylu i kompozycji, wyraźnie zarysowuje autorski podmiot, eksponuje jego subiektywne poglądy, a także igra $z$ przyzwyczajeniami, przeświadczeniami i oczekiwaniami czytelnika; podejmuje $z$ reguły tematykę aktualną $w$ danym czasie, nie jest jednak nigdy oficjalnym komentarzem do wydarzeń. Stanowi zwykle stałą pozycję w dziennikach i tygodnikach. ${ }^{2}$

$Z$ przywołanej definicji wynika, że ważnymi elementami wypowiedzi felietonistycznej sa subiektywizm, emocjonalizm i ekspresja oraz wartościowanie towarzyszące przedstawianym treściom. Autor tekstu wyraża swój stosunek do opisywanych zjawisk i w ten sposób ujawnia swoją subiektywna ocenę, swoje emocje zwiazane $z$ ukazywanymi sytuacjami.

Emocje to rodzaj ekspresji, procesu ujawniania się nadawcy wypowiedzi, ${ }^{3}$ w którym uzewnętrzniają się uczucia. Ekspresywizmy, rozumiane jako

1 P. Stasiński, Poetyka i pragmatyka felietonu, Wrocław-Warszawa-KrakówGdańsk-Łódź 1982, s. 7-10.

2 M. Głowiński, T. Kostkiewiczowa, A. Okopień-Sławińska, J. Sławiński (red.), Podręczny słownik terminów literackich, Warszawa 1997.

3 S. Grabias, Język w zachowaniach społecznych, Lublin 1994, s. 262. 
taki znak predykatywny, w którym obok intelektualnych komponentów konstruktywnych istnieje naddany, indeksalny komponent uczuciowego oglądu treści, ${ }^{4}$

są nieodłącznym elementem felietonów, zwłaszcza Tomasza Raczka, realizującego kanoniczną wersję gatunku. ${ }^{5}$ Felietonista silnie eksponuje swój emocjonalny stosunek do opisywanych faktów, zaznacza ekspresywna postawę wobec rzeczywistości, nie ukrywa swoich ocen dotyczących fragmentów świata, stanowiących temat jego wypowiedzi. Stąd też celem artykułu jest przedstawienie i analiza językowych środków wyrażania emocji, pokazanie stylistycznych operacji zmierzajacych do uwydatnienia ekspresji, będących wyraźnym budulcem stylu autora.

Jedna $z$ technik stosowanych przez Tomasza Raczka w felietonach jest kontrastowanie przedstawionych osobowości telewizyjnych. Podaje on przykłady różnych współczesnych serwisów informacyjnych i osób je prowadzacych, a następnie po kolei je opisuje. Już na poczatku felietonu za pomoca barwnego porównania T. Raczek eksponuje rywalizację między serwisami informacyjnymi, których, wydawałoby się, głównym zadaniem jest podawanie prawdziwych informacji. Jednak felietonista uwidacznia tu ich odmienne cele - przyciagnięcie widzów przed telewizory za pomoca atrakcyjnie podanej treści. Stąd też sięganie po interesujących prezenterów:

(1) Niczym w starożytnym Rzymie co wieczór odbywaja się w Polsce igrzyska. Przed milionami widzów występują gladiatorzy informacji, walcząc między sobą o tytuł króla wieczoru. Prowadza trzy następujacce po sobie serwisy: „Wydarzenia” w Polsacie, „Fakty” w TVN i „Wiadomości” w TVP 1, a telewidzowie nogami (a właściwie w tym wypadku oczami) głosuja na najlepsze źródło telewizyjnej informacji (...) Kto jest, a raczej kto wkrótce okaże się nowym ulubieńcem tłumów? „Wydarzenia” w odprowincjonalizowanym przez Tomasza Lisa Polsacie $z$ Hanna S Smoktunowicz, która posiadła rzadko obecną na małym ekranie sztukę łączenia wiarygodności z seksapilem? A może „Fakty” z monumentalna Justyną Pochanke, która tajemniczość telewizyjnej pytii łączy $z$ błyskotliwym intelektem? Chyba że uda się to odświeżonym „Wiadomościom", w których na razie najlepsze (bo prowadzone $z$ wdziękiem) są sport i pogoda? (...) Nie dajmy się zwieść pozorom: to nie Smoktunowicz, Pochanke, Wysocka czy Durczok decyduja o wartości newsów, które przekazują. Oni sa tylko luksusowymi ekspedientami mającymi za zadanie jak najlepiej je sprzedać. Najważniejszy towar powstaje gdzie indziej - jakość newsów zależy od dziennikarzy, którzy zdobywaja je $z$ kamerą w terenie. Gdzieś w Polsce albo gdzieś w świecie. Zależy od tego, czy uda im się zebrać na własną rękę informacje rozbudowujące zawartość dostępnych dla wszystkich wiadomości agencyjnych i powiedzieć coś, czego inni jeszcze nie wiedza. Zależy od sposobu ich zrelacjonowania. Od talentu do syntezy i błyskotliwej puenty. Od komunikatywności, dociekliwości, wiarygodności, wreszcie od owej tajemniczej telegeniczności, która sprawia, że jednych ludzi pojawiających się na ekranie ogląda się chętnie i z zaciekawieniem, a innych nie [TR 2004a, podkreślenia moje - M.M.].

4 S. Grabias, Pojęcie językowego znaku ekspresywnego [w:] M. Szymczak (red.), Z zagadnień słownictwa współczesnego języka polskiego, Wrocław 1978, s. 112 .

5 Por. M. Wojtak, Gatunki prasowe, Lublin 2004. 
Podstawowymi środkami budujacymi całą tę wypowiedź są: kontrastowanie i metafora. W ten sposób kreowane sa subiektywne oceny, a temu $z$ kolei towarzysza emocje, uczucia, za pomoca których autor wyraża swój stosunek do prezentowanych treści.

W skontrastowaniu tym widoczny jest trójpodział: T. Raczek zestawia i opisuje prowadzacych trzy serwisy informacyjne. Pierwszą omawiana osoba jest Hanna Smoktunowicz. Według autora atutem prezenterki „Wydarzeñ" w Polsacie jest sztuka łączenia wiarygodności z seksapilem, czyli umiejętność połączenia rzetelności zasługującej na zaufanie $z$ atrakcyjnym wyglądem. Felietonista stosuje zestawienie, mogłoby się wydawać, przeciwności, cech społecznie postrzeganych jako wykluczające się. Sa nimi: wiarygodność - od wiarygodny, czyli 'rzetelny, oczywisty, któremu można zawierzyć' oraz seksapil definiowany jako 'atrakcyjność fizyczna', czyli wygląd, który może działać podniecająco na osobę przeciwnej płci.

Druga prowadząca jest Justyna Pochanke $z$ „Faktów” w TVN. Potrafi ona połaczyć tajemniczość telewizyjnej pytii (...) z błyskotliwym intelektem. Pytia przywodzi na myśli osobę, która mówi dwuznacznie, niejasno wyraża swoje zdanie. W dodatku jest ona tajemnicza, czyli ukrywa jakąś tajemnicę, jest zagadkowa lub pełna tajemnic. Tę dwuznaczną zagadkowość prezenterka „Faktów” dopełnia intelektem, kojarzącym się z kompleksowa wiedza i zdolnościami umysłowymi człowieka. Dodatkowo jest on błyskotliwy, co konotuje takie określenia jak zachwycajacy, fascynujacy czy spektakularny. Ponadto J. Pochanke jest monumentalna. Leksem monumentalny przywołuje coś, co ma wielkie rozmiary, jest ogromne czy masywne lub coś, co ma wielkie i trwałe znaczenie, wartość. Opisywane przez T. Raczka osoby łącza zatem niejednorodne cechy, w społecznym odbiorze uznawane za wykluczające się: rzetelność i seksapil (H. Smoktunowicz) czy niejednoznaczność i efektowny umysł (J. Pochanke).

Trzecim członem zestawienia przedstawionego przez felietonistę sa „Wiadomości” emitowane na antenie TVP1, w których opisie T. Raczek ogranicza się jedynie do stwierdzenia, że najlepsze (bo prowadzone $z$ wdziękiem) sa sport $i$ pogoda. Wdzięk konotuje takie pozytywne cechy, które składają się na miłe, dobre wrażenie o jakiejś osobie - to inaczej indywidualny urok, czar osobisty. T. Raczek nie uwzględnia zupełnie w tej relacji ówcześnie prowadzących program informacyjny w TVP1, czyli Kamila Durczoka i Doroty Wysockiej. Wspomina tylko o nich później przy okazji wyliczenia wszystkich omówionych w felietonie prezenterów, suponując tym samym, że prowadzący „Wiadomości” nie mają wdzięku. Pominięcie nazwisk tych prezenterów sugeruje niejako, że D. Wysockiej i K. Durczokowi brakuje ponadto wyrazistości, nie mają oni żadnej cechy, która wyróżniałaby ich, uczyniłaby $\mathrm{z}$ nich osobistości medialne. W ten sposób niewiele mówiąc o prowadzących „Wiadomości”, mówi o nich bardzo dużo, ale nie wprost.

Metafory pojęciowe, czyli „zjawisko charakterystyczne dla ludzkiego myślenia, strukturyzujące doświadczenia człowieka i biorące udział 
w procesach rozumienia", ${ }^{6}$ widoczne sa natomiast już w pierwszych słowach przytoczonego wyżej fragmentu felietonu. W metaforach dominuje przede wszystkim słownictwo militarne i sportowe: co wieczór odbywaja sie $w$ Polsce igrzyska, wysteppuja gladiatorzy informacji, walczac między soba o tytuł króla wieczoru. Konotuje to zacięty bój, walkę i ogromną skalę wydarzenia oglądanego przez miliony widzów. Igrzyska w starożytnej Grecji i Rzymie to były zawody sportowe, muzyczne lub teatralne. Odbywały sie one publicznie w odpowiednio przygotowanych do tego miejscach okręgach świątynnych. Tu igrzyskami sa informacje, a raczej programy je przekazujące. Podczas tych igrzysk walczą między soba o tytuł króla wieczoru, czyli wygrana, gladiatorzy informacji. Królem w przenośnym, potocznym znaczeniu jest ktoś, kto pozytywnie wyróżnia się ze swego otoczenia. Mówimy tak także o kimś najlepszym, kto ma największe wpływy lub najbardziej imponuje pod jakimkolwiek względem. Królem wieczoru jest ten prezenter serwisu informacyjnego, który skupił na sobie uwage widzów, zabłysnął, pozytywnie wyróżnił się czymś wśród innych prowadzących tego dnia wieczorne, o najwyższej oglądalności informacje, okazał się najlepszy. Gladiator natomiast to zapaśnik walczący o swoje życie na arenie $z$ innym siłaczem. Tutaj gladiatorami informacji sa prezenterzy informacji. Walczą oni między sobą o to, kto $z$ nich danego dnia zwycięży, kto zdobędzie uwagę odbiorców, zainteresuje swoim przekazem, pokona pozostałych gladiatorów, okaże się gigantem, najlepszym prezenterem. Te metafory konotujacce walkę, wojnę czy sport degraduja opisywane za ich pomoca osoby - deprecjonują znaczenie prezenterów newsów.

Podobny zabieg widoczny jest w kolejnej metaforze pojęciowej, w której prezenterów T. Raczek nazywa tylko luksusowymi ekspedientami majacymi za zadanie jak najlepiej je [newsy - dop. M.M.] sprzedać. Ekspedient to człowiek sprzedajacy towary w sklepie, sprzedawca, którego zadaniem jest handel tym, co jest w sklepie. Sprzedawcy ci sa luksusowi, ponieważ nie zajmują się zwykłym zbywaniem rzeczy, ale staraja się jak najlepiej odsprzedać informacje i przy okazji siebie samych, swój wizerunek. Jednak wiadomości te nie sa wynikiem pracy samych prezenterów - newsy zdobywaja inni dziennikarze, a prowadzacy wieczorne wydania informacji maja je tylko sprzedać jak największej liczbie widzów. Tutaj również metafora związana ze sprzedaża pełni funkcję nie tylko uplastycznienia przekazu czy przybliżenia nam tematyki pracy dziennikarzy telewizyjnych w obrazowy sposób, ale przede wszystkim jej zadaniem jest pokazanie subiektywnego, emocjonalnego spojrzenia $\mathrm{T}$. Raczka na omawiany temat.

Potrójne zestawienie felietonista wykorzystuje także do charakterystyki dziennikarzy, Tomasza Lisa, Moniki Olejnik i Grzegorza Miecugowa, oraz sposobów prowadzenia przez nich rozmowy, które określa za pomoca anglicyzmów.

6 B. Kuryłowicz, Idiostyl a metafora pojęciowa [w:] U. Sokólska (red.), Socjolekt-idiolekt-idiostyl. Historia i wspótczesność, Białystok 2017, s. 65. 
(2) Powstaje więc dramatyczne pytanie: $z$ kim dzisiaj warto rozmawiać w telewizji? Ten dylemat staje zapewne przed trójka tych, którzy telewizyjne rozmowy traktują najpoważniej i dzięki temu mają w tej dziedzinie sukcesy. Proponują zresztą trzy zupełnie różne typy dialogu.

Monika Olejnik, czyli acid talk. Jej wywiady sa przyprawione na kwaśno - nie tylko miną zawsze zdegustowanej prowadzącej, ale także dającym się wyczuć rozczarowaniem wobec zaproszonych gości. Tak jakby siadając do rozmowy, z góry wiedziała, że niewiele może się po nich spodziewać, ale skoro żyć trzeba i dowiedzieć się, jak naprawdę jest, też trzeba, to - mimo iż czuje nies mak - stawia politykom pytania. Mimo wszystko ma się jednak wrażenie, że Monice Olejnik ciagle jeszcze zależy. Że nie wygasła w niej pasja. Ma żar. Kwaśny, ale goracy [TR 2004b, podkreślenia moje - M.M.].

Rozmowy prowadzone przez Monikę Olejnik Tomasz Raczek określa jako ang. acid talk, czyli kwaśna dyskusję. Użyta w tym fragmencie felietonu leksyka dotyczy zmysłu smaku, kulinariów, które wprowadzają przenośne znaczenie. Prowadzaca jest zawsze niezadowolona, zawiedziona i odczuwa niesmak. Metaforę tę zapowiada już wstępne angielskojęzyczne określenie stylu dialogu M. Olejnik - acid talk. Negatywnie nacechowane leksemy opisuja postawę dziennikarki: zdegustować konotuje wywołanie czyjejś niechęci czy zrażenie do czegoś lub kogoś; rozczarować się natomiast kojarzy się $z$ utratą złudzeń w stosunku do kogoś lub czegoś albo zawiedzenie się na kimś lub na czymś; niesmak w znaczeniu przenośnym przywołuje konotacje obrzydzenia, odrazy lub jakichś przykrych wrażeń bądź uczucia niechęci. Jednak leksemy te zneutralizowane zostały przez następne określenia typu: ciagle jeszcze zależy; nie wygasła w niej pasja; Ma żar. Kwaśny, ale goracy. Strategicznym słowem w opisie dziennikarki jest jednak pasja, która synonimicznie określana jest przez dotykowo skojarzony żar, który bywa kwaśny, ale jest goracy. Felietonista za pomoca tej metafory pojęciowej przedstawia Monikę Olejnik, która w swoich rozmowach pokazuje niezadowolenie. Jednak rozmowa prowadzona przez nia jest także pełna zapału i żarliwości.

Podobne określenie sposobu prowadzenia rozmowy, tym razem za pomoca anglicyzmu lounge talk, czyli rozmowa salonowa, pojawia się we fragmencie felietonu mówiącym o innym dziennikarzu:

(3) Tomasz Lis, czyli lounge talk. Nowy wizerunek Lisa jest salonowy. Lis zwraca uwage na to, jak wygląda i czy do twarzy mu w otoczeniu ludzi, których zaprasza do studia. Jest pewnym siebie gospodarzem salonu, który rezerwuje sobie prawo rozdawania przywilejów. Gości traktuje z szacunkiem, dbając jednak zawsze, by jak kiedyś Irena Dziedzic - górować nad nimi wdziękiem i elokwencją. Udaje mu się to zresztą. Pomimo tego nikt mu nie odmawia. Być może dlatego, że Lis także ma pasję. Pytania, które stawia, pochodzą $z$ głowy, a nie $z$ kartki, a sprawy, o które pyta, obchodza go do tego stopnia, że w jego oczach pojawia się niemal gorączka. Ta właśnie lisia gorączka jest gwarancja wysokiej oglądalności programu [TR 2004b, podkreślenia moje - M.M.].

Tomasz Lis porównany został do Ireny Dziedzic - gracją i darem wymowy dziennikarz stara się górować nad rozmówcami, zarazem jednak okazuje im szacunek. Podczas programu dotyka spraw, które są mu bliskie, do tego stopnia, że w jego oczach pojawia się niemal goraczka. Me- 
tafora pojawiającej się komuś w oczach goraczki została w tym felietonie przekształcona - to modyfikujacca innowacja rozwijajaca ${ }^{7}$ frazeologizmu oczy komuś się zaświeciły do kogoś lub do czegoś, który oznacza, że ktoś jest kimś lub czymś bardzo zainteresowany, a świadczy o tym błysk w oczach. Dziennikarz stara się być niewzruszony i spokojny - jedynie jego oczy wyrażaja silne emocje. Lisia goraczka to metaforyczne ujęcie pasji, z którą Tomasz Lis oddaje się prowadzeniu rozmów na antenie telewizji. I właśnie ta pasja, goraczka w oczach i lisia goraczka są najważniejszymi słowami w opisie tego dziennikarza.

W analogiczny sposób, za pomoca anglicyzmu i pojęcia pasji, T. Raczek przedstawia trzeciego dziennikarza w tym felietonie - Grzegorza Miecugowa:

(4) Grzegorz Miecugow, czyli classic talk. W TVN 24 jest skromny niedzielny program „Inny punkt widzenia”. Zaglądam tam niczym do oazy klasycznej inteligenckiej rozmowy, w której spokojnie przedstawiane argumenty rozpędzają myśli tak mocno, że sięgaja po horyzont. Ale Miecugow nie zaprasza polityków. Jego gośćmi są intelektualiści, pisarze, reżyserzy. W tym założeniu jest niezwykła stanowczość Miecugowa i... jego pasja: nie chce pozwolić odejść od telewizji inteligentom [TR 2004b, podkreślenia moje - M.M.].

Sposób prowadzenia rozmowy przez Grzegorza Miecugowa, określony mianem classic talk, to rozmowa klasyczna, wzorcowa. T. Raczek podkreśla stanowczość dziennikarza, co oznacza, że umie on powziąć kategoryczna decyzję, nie ulega wahaniom, jest zdecydowany. Jego determinacja dotyczy zatrzymania inteligentów przy swoim skromnym programie, który jest jak oaza. G. Miecugow jest twórca takiego właśnie wyizolowanego miejsca, w którym każdy może znaleźć spokój lub wytchnienie. Dziennikarz prowadzi zwyczajny, przyzwoity i niewyzywajacy program, a w nim w skromny sposób uwypukla giętkość i przenikliwość umysłu zaproszonych gości i swojego. Program taki współcześnie jest rzadkościa. Przenośnia klasycznej inteligenckiej rozmowy konotuje doskonałość i wzorcowość dialogu intelektualistów. Natomiast metafora ukazująca argumenty, które rozpędzaja myśli tak mocno, że sięgaja po horyzont, przywodzi na myśl nieograniczone niczym spojrzenie na omawiany problem. Ten opis dziennikarza również kończy się ważnym słowem - pasja. Taka namiętność G. Miecugowa do intelektualnych rozmów połączona $z$ jego stanowczościa, pozwala na stworzenie odosobnionego i kameralnego miejsca telewizyjnego.

Każdy $z$ charakteryzowanych przez $T$. Raczka dziennikarzy realizuje odmienny wariant dyskusji, jednak wszyscy odnieśli sukces dzięki temu, że telewizyjne rozmowy traktuja najpoważniej. Istotnym słowem w opisie pracy wszystkich trojga dziennikarzy telewizyjnych jest pasja. Te oso-

7 S. Bąba, Innowacje frazeologiczne współczesnej polszczyzny, Poznań 1989, s. 51 . 
bistości medialne bardzo różnią się od siebie, a zatem ich style także są odmienne. Łączy je jednak to, że okazuja wielkie zamiłowanie do swojej pracy, przejmują się tym, co robia zawodowo i to przeradza się w namiętność, czyli jednoczy je właśnie pasja: Że nie wygasła w niej pasja (o Monice Olejnik), Być może dlatego, że Lis także ma pasję (o Tomaszu Lisie), W tym założeniu jest niezwykła stanowczość Miecugowa i... jego pasja (o Grzegorzu Miecugowie). Konfrontacja trójki prezenterskich gwiazd służy z jednej strony uwypukleniu różnych osobowości, charakterystycznych cech stanowiących o ich indywidualizmie, $z$ drugiej natomiast - jej zadaniem jest wyeksponowanie tego, co je łączy i stanowi o istocie ich pracy.

Charaktery, style trójki dziennikarzy T. Raczek zestawił ze soba- wyliczył ich cechy pozytywne, a negatywne przedstawił w taki sposób, by w ogólnym rozrachunku także wydały się pochlebne.

Podsumowujac, w analizowanych felietonach Tomasz Raczek swój emocjonalny, ekspresywny stosunek do opisywanych postaci ukazał za pomoca kontrastu. Po pierwsze, przedstawił różnice między opisywanymi osobowościami telewizyjnymi. Wymienił Hannę Smoktunowicz, Justynę Pochanke, a innych dziennikarzy (Dorota Wysocka i Kamil Durczok) nie tylko pozbawił imion, ale także pominą ich w swoich rozważaniach. Wskazał ich nazwiska na końcu, niejako przy okazji szeregowania wszystkich prezenterów omawianych przez siebie programów informacyjnych. Po drugie, krytyk filmowy posłużył się porównaniem, współczesnego dziennikarza Tomasza Lisa zestawił $z$ wzorcowa postacia mediów, Irena Dziedzic, której sposób przekazywania informacji wyznaczył drogę polskim prezenterom. Po trzecie, T. Raczek, konfrontując osobowości telewizyjne, zastosował waloryzujące w opisie anglicyzmy: acid talk, lounge talk, classic talk. Po czwarte, felietonista skorzystał $z$ wyszukanej i wartościujaccej metaforyki. Jego metafory waloryzujące należą do sfery kulinarnej - reprezentujacej zmysł smaku, dotyku, powonienia (metafory synestezyjne), np. acid, kwaśny, ale goracy, niesmak, wojennej, np. gladiatorzy informacji, czy sportowej, np. igrzyska. W ostatnim przykładzie sam leksem igrzyska jest neutralny semantycznie, a dopiero w kontekście zyskuje nacechowanie dodatnie. Deprecjonujace metafory natomiast pochodza $z$ domeny handlu - wskazuja na ironiczny stosunek do opisywanych zdarzeń i osób, np. luksusowymi ekspedientami T. Raczek nazywa dziennikarzy sprzedających informacje i swój wizerunek. Ponadto metafory tego samego pojęcia dopasowane zostały przez niego odpowiednio do każdej $z$ opisywanych osobowości - pasja ma tutaj wiele wariantów: ciagle jeszcze zależy, żar, kwaśny, ale goracy. W innym wypadku w oczach pojawia się niemal goraczka, lisia goraczka. Czy też argumenty rozpędzaja myśli tak mocno, że sięgaja po horyzont.

$\mathrm{W}$ felietonach Tomasza Raczka zawarte jest emocjonalne spojrzenie na rzeczywistość. Ekspresję wypowiedzi osiagną on za pomoca rozmaitych środków artystycznego wyrazu, które stanowią o jego indywidualnym stylu. 


\title{
Bibliografia
}

S. Bąba, 1989, Innowacje frazeologiczne wspótczesnej polszczyzny, Poznań.

S. Grabias, 1978, Pojęcie językowego znaku ekspresywnego [w:] M. Szymczak (red.), $Z$ zagadnień słownictwa współczesnego języka polskiego, Wrocław, s. $107-115$.

S. Grabias, 1994, Jezzyk w zachowaniach społecznych, Lublin.

M. Głowiński, T. Kostkiewiczowa, A. Okopień-Sławińska, J. Sławiński (red.), 1997, Podręczny słownik terminów literackich, Warszawa.

B. Kuryłowicz, 2017, Idiostyl a metafora pojęciowa [w:] U. Sokólska (red.), Socjolekt - idiolekt - idiostyl. Historia i współczesność, Białystok, s. 65-74.

P. Stasiński, 1982, Poetyka i pragmatyka felietonu, Wrocław-Warszawa-Kraków-Gdańsk-Łódź.

T. Raczek, 2004a, Gladiatorzy informacji, „Wprost” nr 44, s. 74.

T. Raczek, 2004b, Z kim warto rozmawiać, „Wprost” nr 46, s. 68.

M. Wojtak, 2004, Gatunki prasowe, Lublin.

\section{Linguistic methods of expressing emotions. Tomasz Raczek about journalists}

\author{
Summary
}

In the first part of the text entitled Linguistic methods of expressing emotions. Tomasz Raczek about journalist, the author presents Tomasz Raczek's writing, in particular his feature articles, where the columnist refers to the contemporary social life from the perspective of film and television criticism.

In the subsequent parts of the text, the author describes selected components of the history of feature articles and presents some definitions of a feature article, and then focuses on the linguistic aspects of a subjective way of expressing the emotions and feelings accompanying the description of mass media personalities. The author pays a special attention to the techniques used by Raczek, for example putting things very close together in order to show a contrast, using metaphors and anglicisms to describe media personalities.

In the last part of the text, the author juxtaposes the previously described techniques of the columnist, sums up the discussions on the linguistic methods of expressing emotions and feelings in Tomasz Raczek's feature articles.

Keywords: linguistic methods of expressing emotions and feelings - feature article - Tomasz Raczek - journalist - subjective way of expresssing emotions and feelings 